\title{
Systems of Vegetal Façade and Green Roofs used as a Sustainable Option in Architecture
}

\author{
M. Chanampa, Technical University of Madrid, Madrid, Spain \\ P. Vidal Rivas, Technical University of Madrid, Madrid, Spain \\ J. Alonso Ojembarrena, Technical University of Madrid, Madrid, Spain \\ F. Olivieri, Technical University of Madrid, Madrid, Spain
}

\begin{abstract}
Green architecture contributes not only in reducing the building's thermal loads but also in reducing the effects of the urban heat island in densely built-up areas in a hardly natural environment. The current green systems are built in situ/on site and are very expensive, hence the need to create industrialized prevegetated systems which improve the buildings' energy savings and reduce the times of construction works. The present paper describes three green systems for façades (gabion façade, green sliding panel, green panel in plastic cell) and two prevegetated green tank roof systems (green roof in light concrete and pvc).
\end{abstract}

Keywords: Ventilated Façade, Green Rooftop, Energy Saving, Bioclimatic Architecture, Green Wall, Evaporative Cooling

\section{Introduction}

$\mathrm{N}$

OWADAYS THE LACK of vegetation, added to the use of masonry materials and to pollution, causes a significant rise of the urban temperature producing what we know as urban heat island effect. Specifically in the city centers, the urban heat island in the summer is caused by the absorption of the high solar radiation by the urban surfaces [1]. This rise of the temperature causes an increase of the cooling energy use (air-conditioning machines) and accelerates the formation of urban smoke, so these unpleasant conditions should be moderated before affecting the health of human beings [2]. The biological activities of the foliage may lower the indoor-outdoor air temperature and save cooling energy use in buildings. Consequently, green covering becomes the only promising and stabilizing choice in the present scenario [3].

\section{Vegetal Constructive Solutions}

\section{Green Walls}

\section{Vegetal Gabion Façade}

The vegetal gabion system is an optimal façade solution. Stones of different colors, textures and grains as well as vegetable species can be selected within a wide range of possibilities. This suggested industrialized and sustainable system puts together stone and vegetation in a same module to be part of the constructive elements in the buildings' façades. The vegetal 
gabion façade consists of 55 x $55 \mathrm{~cm}$ modules (21,6 inches x 21,6 inches). Each module is constituted by several elements that are available in the market and don't require advanced technology: galvanized welded mesh, stones of different grading and a plastic cell (replaceable by a metal box) with substrate for the development of plants. As complementary components, the system includes thermal insulation and a galvanized steel structure.

The metallic mesh provides the structure for the stones. It has to be galvanized so that it's protected from corrosive effects and should have a 50 x $50 \mathrm{~mm}$ opening. A bigger opening with a smaller diameter makes the structure less resistant. The diameter suggested is 3,55 $\mathrm{mm}$ with a protection (zinc and aluminum) against extreme climate and corrosion. The joints among faces are done with high resistance wire staples of $3 \mathrm{~mm}$. It is necessary to set $4 \mathrm{~mm}$ galvanized wire tensors every $20 \mathrm{~cm}$. The tensors link the faces in order to prevent deformations, while the staples make the Gabion into a monolithic piece.

The stones selected should have a volcanic origin. The diameter of the stones placed inside varies from $60 \mathrm{~mm}(0,23$ inches) to $90 \mathrm{~mm}(0,35$ inches). Some of the stones that can be incorporated into the gabions are pumice (density $400 \mathrm{~kg} / \mathrm{m} 3$ ), volcanic rock (density 1600 $\mathrm{kg} / \mathrm{m} 3$ ) and porous rock (density 1700 to $2500 \mathrm{~kg} / \mathrm{m} 3$ ). The stones sold with these characteristics are the Rock Spaghetti, Red Rainbow Bolo, Bolo Green Rainbow and different types of Rocallas. All of them are supplied in cages, pallets or bags, depending on the volume needed. Cages can load up to $1000 \mathrm{~kg}$.

The vegetation chosen are plants that grow in rocks hollows. The plant species are selected depending on where this system is developed, they must be tolerant to adverse weather conditions and require little maintenance. The gabion structure (see Fig.1.) should provide the possibility of replacing the plant if its development in a module is not correct.

The system allows the use of several vegetal species which offer changing visuals elements throughout the year. This variable appearance depends on diverse aspects such as the stones texture, color, persistent foliage or not, foliage density, plants color, etc. It is better to use those of fast growth that don't require much soil care and can easily multiply, like small mosses which require moisture to live and ferns that need high humidity and areas with low light. 


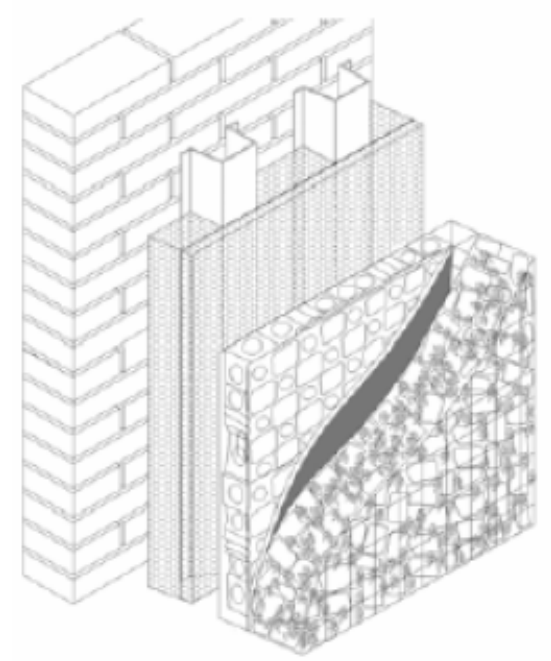

Fig.1: Module Perspective View

In order to improve the vegetation growth, its roots must be inside a substrate with essential nutrients. To do that we use a plastic cell called "Atlantis" (made of recyclable polypropylene) that has holes which allow the introduction of humus, polymers, potassium salts and vermiculite, which is placed inside the Gabion. The cell is rectangular, perforated horizontally and vertically. Atlantis pieces are joined two by two, because each piece measures $26,5 \mathrm{~cm}$ $\mathrm{x} 47,5 \mathrm{~cm} \times 0,52 \mathrm{~cm}(10,42$ inches $x 18,68$ inches $x 0,20$ inches $)$, the hole size is $0,55 \mathrm{~cm} \mathrm{x}$ $0,55 \mathrm{~cm}(0,21$ inches $\mathrm{x} 0,21$ inches $)$ and it weights $0.45 \mathrm{~kg}$.

Polymers or hydro-gels are elements that increase the substrate capacity to retain water and reduce the need for irrigation allowing the use of low quality water. Water, fertilizers and stimulators are absorbed and stored in the root zone. The dose to cover the plants should be between 100 to $150 \mathrm{~g} / \mathrm{m}^{2}$.

The substrate is vital for the sustenance of the vegetation, being the source of food and shelter of the roots. Another key element is drip irrigation which entails applying small amounts of water in localized areas with a variable number of emission points.

Once constructed as a monolithic piece the gabion is placed on a metal grid that acts as the support element where the modules are established.

The thermal insulation (extruded polyestyrene) applied is selected according to the climatic zone, has a correct porosity for vapor diffusion and it is sold in a modular form. This kind of insulation is located between the metal structure to satisfy the transmittance required by the Spanish legislation. It has to be rustproof due to the contact with moisture generated by the plants and the irrigation itself. Moisture reduces the ability to limit the flow of energy between inside and outside. This element improves the ventilated façade insulation and the thermal performance of the walls by reducing the heat bridges as well as problems related condensations (see Fig.2.). 


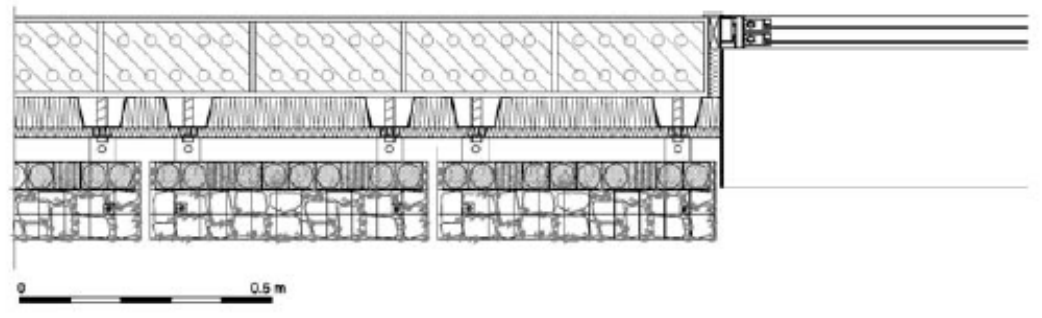

Fig.2: Module Horizontal Section

The link of the gabions to the structure is accomplished by angular anchorages leaving an air gap between the interior wall and the external cladding (gabion). These anchors have to be able to withstand wind forces and impacts, and they must be galvanized in order to prevent corrosive effects and allow modules substitutions if necessary.

\section{Sliding Panel}

This constructive design consists of a mobile solar protection for translucent façades. It incorporates creeper plants whose main role is to cast a shadow on the enclosure. The system works as a sliding cover (see Fig.3.) and can be used as a façade with entrance of light. It is an outer envelope with a different bioclimatic function and appearance according to the vegetal species selected, depending on the orientation of the building.

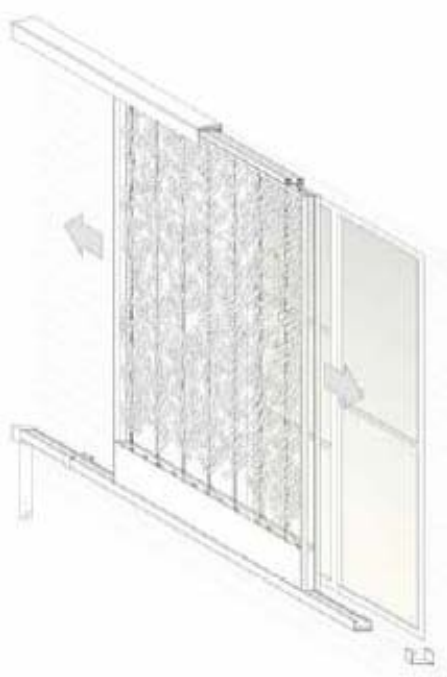

Fig.3: General View of the Sliding Panel System

Despite of being a mobile constructive solution, this industrialized design offers an innovative characteristic consisting of the incorporation of a continuous plant irrigation system. The whole system is hung from a structure on an exterior wall: a metallic framed panel with creeper vegetal species moves through horizontal guides. The panel has a metallic plant container where the vegetal plant grows and a continuous gutter is placed underneath. The 
water inside the gutter never has contact with the substrate. Both are connected by porous wicks, keeping the substrate wet but not flooded. The creeper plant has roots inside the plastic cells filled with substrate. These plastic cells are wrapped in felt.

An important part of the water can be recyclable.

The substrate must be neutral enough for the plant growth. In order to prevent excessive dryness and to retain water in the extended summer periods elements are included in the substrate. The kind of creeper plant species varies with the climate conditions where this system is applied and its orientation. After considering several deciduous creeper species for the specific case of Madrid, the ones chosen have:

- Short root development. This condition is directly related to the size of the plant pot where the roots are in. Thus, to achieve a minimum substrate thickness (about $10 \mathrm{~cm}$ ) this element needs to have a depth of $25 \mathrm{~cm}$. These minimum dimensions also ensure sufficient root protection against direct solar radiation.

- Growth control of a defined volume. Having lesser maintenance in the industrialized system is an important value in social housing. Therefore, it is important that the creeper species do not require pruning or additional uncomfortable work. It is necessary to guarantee a maximum development capacity of the green cover's plant species selected.

Based on these criteria, using species such as the climbing hydrangea (Hydrangea petiolaris), and yellow jasmine (Jasminum nudiflorum and Jasminum fruticans) or forest honeysuckle (lonicera periclymenum and lonicera etrusca) is considered adequate. In north exposure deciduous species are not appropriate, in these cases perennials such as small ivy leaves (Hedera helix).

In addition to incorporating vegetation of easy implementation and quick replacement, this system allows a better controlled germination in nursery. Some advantages of this technique are that vertical gardens do not consume urban surface and need little maintenance work. Moreover, these green-inputs turn conventional windows into fragrant or productive ones. Depending on the creeper type and façade openings they may become domestic vegetable gardens with particular vegetal species.

\section{Vegetal Draining Plastic Cell}

Vegetated cell panels (see Fig.4.) are made of Atlantis polypropylene draining-cells with a $90 \%$ porosity. The holes are filled with a substrate previously studied. Finally this element is wrapped with wool felt, $2 \mathrm{~mm}$ thick and a $0.55 \mathrm{~g} / \mathrm{cm} 3$ density. As a result of this a compact module is placed in parallel to the façade. Incisions are made in one side of the felt to set plants, that are drip irrigated.

An automatic irrigation system using drip ducts provides water to the panels. Drip irrigation consists in applying small amounts of water to localized areas. The distribution polypropylene tubes (16 $\mathrm{mm}$ diameter) are combined with the $4 \mathrm{~mm}$ ones located at the top. 

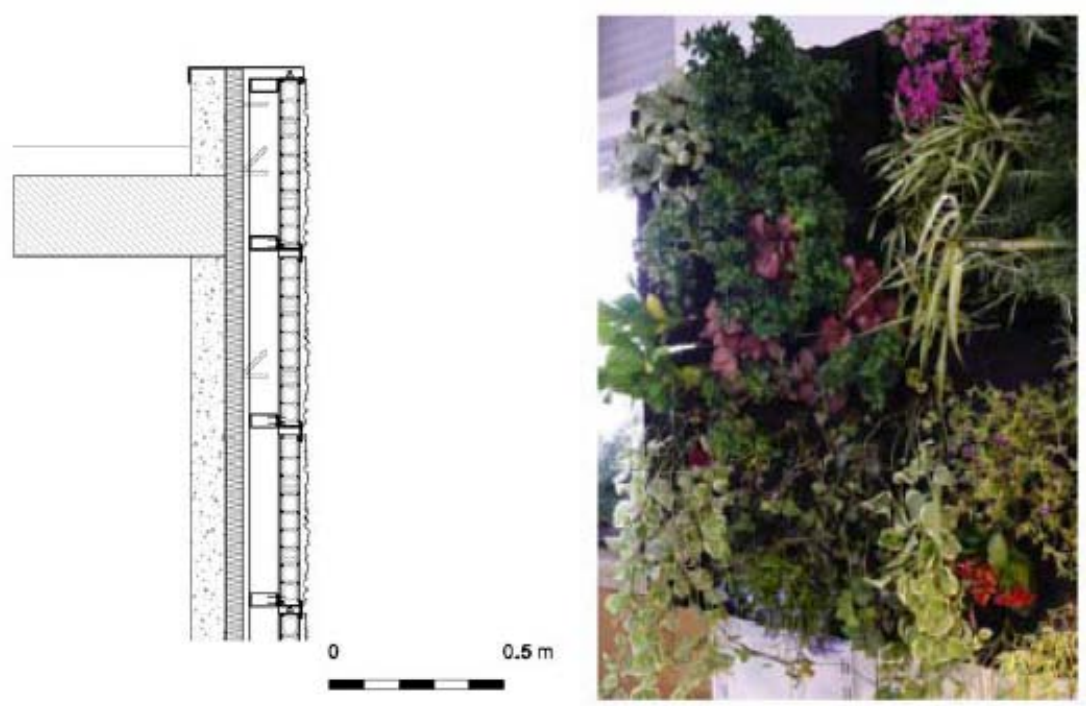

Fig.4: Prototype Built and Constructive Section of the Solution

These microtubules are installed to operate optimally at a 1.5 bar pressure. The excess of water is collected so that water is recycled for irrigation.

The most commercial greenery-façade systems studied use sedum plants, coming from early researching. These are hardy species, and they are dry environments' plants used in extensive green roofs. However, sedum hardly grows the same way in south-faced façades. Because of the summer's excessive sun radiation new plants have had to be selected. The use of native and acclimatized species is one of the main objectives. Some of them have been tested in south orientation, such as drosanthemun hispidum. When there is no direct sun radiation, the plant species are chosen taking into account their covering capacity, like small-leaved hedera helix, and also the use of less-hardy species such as gardenia jasminoides or moss.

This upholstering and climbing capacity mitigates the discontinuous cladding effect caused by the constructive system designed, and it is also decisive for the plants selection. When the vegetation develops as a continuous wall, monitoring becomes much more representative. The panelling system restricts species with roots able to grow in $52 \mathrm{~mm}$ width, with a more important horizontal development. The roots will fill the whole panel, stopping also its foliage growth and saving the costs of maintenance pruning.

\section{Green Roofs}

Many design possibilities and advantages related to energy savings are achieved by using alive green roofs. The installation of this system is well adapted to flat roofs (zero slope). The constructive design incorporates a rainwater tank (3,1 inches height) that entails the following benefits: a continuous plant supplying by capillarity, temperature oscillations in the roof, noise absorption and passive fire prevention. Rainwater could be also reused for wc tankers. 
The slow growth of vegetation is a common disadvantage in current green roofs. Conventional systems usually require three or more years in order to be definitely set as well as a continuous maintenance work. Because of this reason, a prevegetated modular green tank integrated in the roof system has been studied. The vegetation species and the thermal insulation applied are selected according to the climatic zone and the roof site regulations. The module design has been researched with two different components. The first one that was built was made of lightweight concrete which permits an efficient passage of the water excess into the tank. It is a highly resistant and $100 \%$ recycled element. However, it does not constitute a definitive constructive solution due to its heavy weight. The second module built was made of PVC. Despite the component being lighter than the first prototype it has a higher life cycle.

The roof area is divided into these modules. These industrialized elements (see Fig.3.) work as a support and drainage system for the ecological substrate $(3,5$ inches) where autochthonous vegetation is planted. The vegetal species selected (Succulent ground covers, water conserving accent plants) are highly resistant to extreme temperatures and do not need any maintenance work.

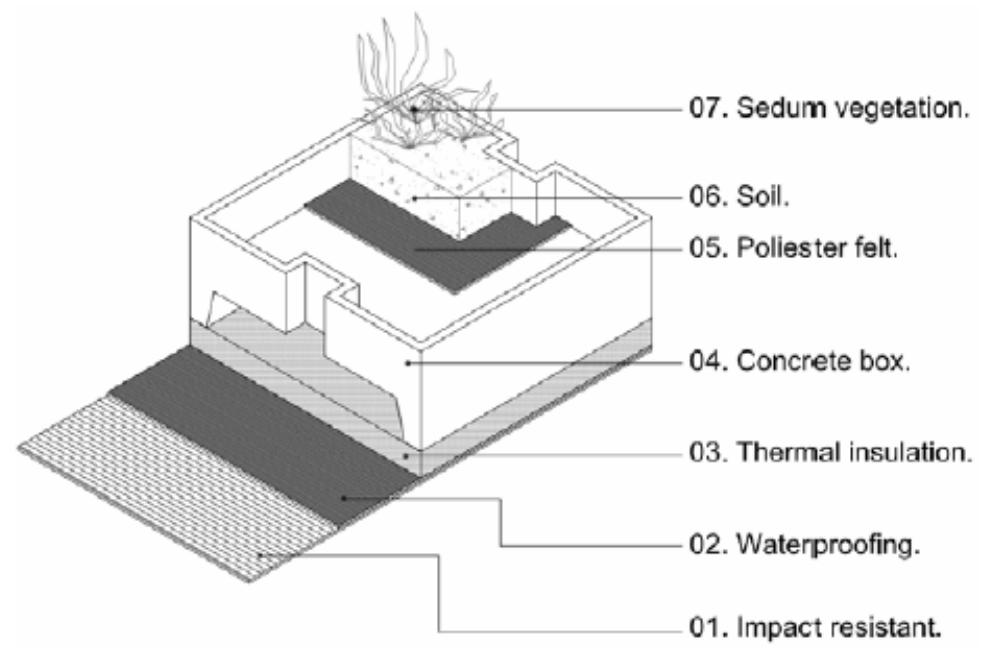

Fig.3: Roof System Constructive Perspective

A large number of plant species are used to make sod (sedum, fescue or creeping rosemary), which are more or less native, so those species best adapted to climate conditions colonized the roof. In general, they are all species that developed with minimal water resources and limited substrates, requiring no constant maintenance or pruning [4].

For its effectiveness well-drained soil is essential. The light concrete plays a main function here, facilitating excess water evacuation. The substrate is involved in the complex process of plant mineral nutrition. For the vegetation type chosen, with a minimum root growth, the substrate needs to be poor and well drained like a mixture of common earth, worm compost, sand, vermiculite, expanded clay and debris dust.

A polyester fiber felt provides water from the rainwater tank. The modules' size of 60x60 $\mathrm{cm}(23,6$ inches $\mathrm{x} 23,6$ inches) allows their transport. The system has an ergonomic design 
(see Fig.4.) that permits one person to do a fully transport of the vegetated modules. The modules present an easy maintenance as well as a reduction in final labor costs.

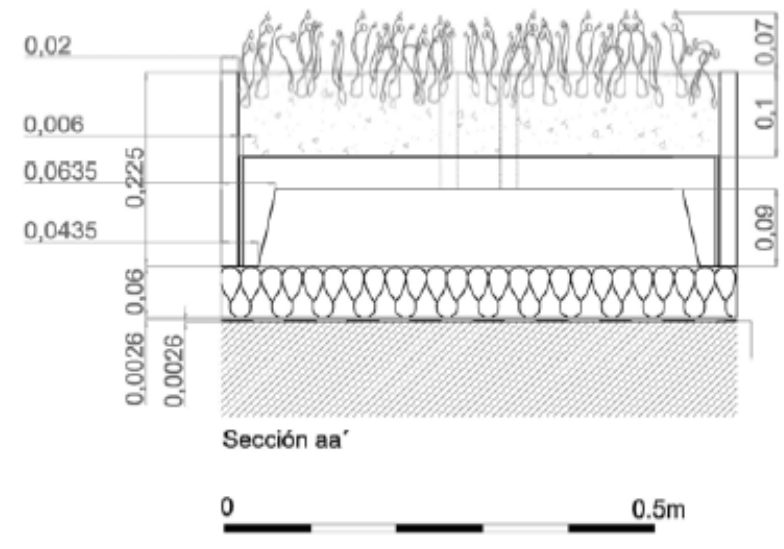

Fig.4: Roof System Constructive Section

Industrialization, universality and energy efficiency are additional benefits of the strategy. Experimental samplings demonstrate that the system obtains an optimal operation from its first day implementation. It is also a constructive solution that needs to be readjusted through an optimal plant selection and insulation according to the climatic zone.

\section{Environmental Benefits}

The vegetation carries out two particular functions in these systems:

1. Intercepting sunlight before the building gets warm, it is an energy saving instrument that controls solar radiation in the summer as well as avoiding overheating and temperature fluctuations inside the buildings (see Fig.5.);

2. Decreasing wind speed [5].
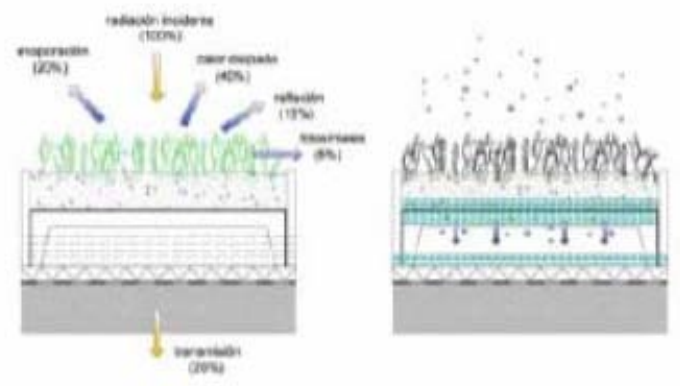

Fig.5: Solar Control and Rainwater Tank 

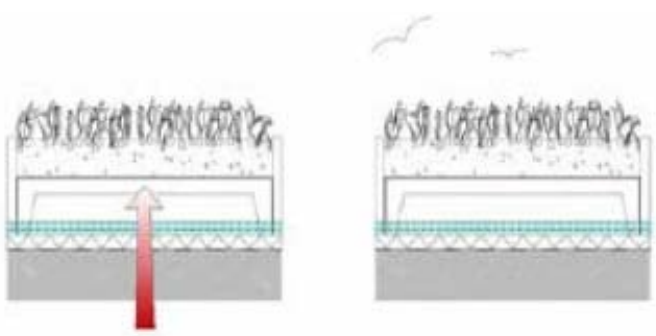

Fig.6: Thermal Insulation and New Natural Spaces

The sliding panel generates breeze through the windows during the summer. The cool surfaces provided by the leaves can be effective in reducing the energy used for cooling and heating [6]. The vegetation acts as a cooling element due to evapotranspiration [7], a process based on the evaporation of water in the vegetation and surrounding soil.

During the winter, the strategies work as an organic insulation in order to prevent indoor energy losses. Besides, the air quality is improved, as a consequence of the photosynthesis process, by providing $\mathrm{O} 2$ and absorbing $\mathrm{CO} 2$. In addition to the air quality improvement these techniques with vegetation are a microclimate modifier.

The incorporation of vegetation in buildings or large-scale projects like squares turns it into a living element inside the city, where green areas are scarce. This generates several positive impacts for environment and also improves the human well-being of the citizens. These industrialized constructive strategies help not only to enhance the sustainability of the buildings but also to diminish the urban pollution.

Integrating vegetal species in Architecture has benefits such as increase of the humidity, control of the solar radiation, decrease of the air temperature, thermal insulation, aesthetical effects, and psychological well-being. Vegetal species work as a skin protection that reduces deterioration in relation with the façades exposed to extreme climate conditions. Fauna and flora development, as well as the creation of natural spaces in the cities are other positive impacts regarding these systems. (see Fig.6.).

As a sustainable solution, every component is recycable or recycled (aluminum, polyethylene).

\section{Innovations}

These are interesting solutions that require further studies in order to make known the positive influence of green walls and roofs. Some of them have other applications and the changes proposed give them new uses. For example the gabions have been designed in order to built walls that could retain land or displacements. They also prevent the erosion of fertile soils due to rains. Besides, the gabions control the rise of the rivers' level, protecting populations from floods. Other uses are part of the drainage systems that facilitate water filtering, noisereduction screens, border elements in green places. They have not worked as green masonry protection that could produce energy savings.

Vegetal solutions are conceived as industrialized constructive systems that save time during installation. Vegetal species act as environmental comfort modifiers that intend to allow better conditions for future generations. These prototypes entail spatial innovation and a relatively easy application in housing. 


\section{Acknowledgements}

The present research has been developed in the INVISO Project (Industrialization Sustainable Housing). The prototype of vegetal panel in cellular plastic draining cell will be built in the Environmental Area of Pozuelo de Alarcón (Spain). The building has been designed by Antonio Baño and was funded by the Pozuelo de Alarcón city council.

\section{References}

[1] Akbari, H; Pomerantz, M; Taha, H (2001) "Cool surfaces and shade trees to reduce energy use and improve air quality in urban areas", Solar energy, Elsevier Science Ltd, Great Britain, Vol. 70 pp. 295-310.

[2] Alexadri, E; Jones, P (2008) "Temperature decreases in an urban canyon due to green walls and green roofs in diverse climates", Building and Environment, Elsevier Science Ltd, Great Britain, Vol. 43 pp. 480-493

[3] Kumar. R; Kaushik. S (2005) "Performance evaluation of green roof and shading for thermal protection of buildings", Building and Environment, Elsevier Science Ltd, Great Britain, Vol. 40 pp. $1505-1511$

[4] Neila, F; Bedoya, C; Acha, C; Olivieri, F ; Barbero, M. (2008) "Las cubiertas ecológicas de tercera generación: un nuevo material constructivo", Informes de la Construcción, vol. 60, no. 511.

[5] Falcón. A. (2007) "Espacios verdes para una ciudad sostenible”, 1st ed., Gustavo Gili, Barcelona, Spain.

[6] Neila González. J. (2004) “Arquitectura Bioclimática en un entorno Sostenible”, 1st ed., MunillaLería, Madrid, Spain.

[7] Onmura,S; Matsumoto,M; Hokoi, S (2001) "Study on evaporative cooling effect of roof lawn gardens", Energy and Building, Elsevier Science Ltd, Great Britain, Vol. 33 pp. 653-666

\section{About the Authors}

M. Chanampa

Technical University of Madrid, Spain

P. Vidal Rivas

Technical University of Madrid, Spain

\section{J. Alonso Ojembarrena}

Technical University of Madrid, Spain

F. Olivieri

Technical University of Madrid, Spain 